\title{
Jurist-Diction
}

Volume 3 No. 5, September 2020

\section{Tindak Pidana dan Pertanggungjawaban Pidana Pelaku Penyalahgunaan Senjata Tajam}

\author{
Rakyu Swanabumi Rahmantara Rosady \\ rakyurosady@gmail.com \\ Universitas Airlangga
}

\author{
How to cite: \\ Rakyu Swanabumi Rahmantara \\ Rosady, 'Tindak Pidana dan \\ Pertanggungjawaban Pidana \\ Pelaku Penyalahgunaan Senjata \\ Tajam' (2020) Vol. 3 No. 5 \\ Jurist-Diction. \\ Histori artikel: \\ Submit 24 Juli 2020; \\ Diterima 14 Agustus 2020; \\ Diterbitkan 1 September 2020. \\ DOI: \\ 10.20473/jd.v3i5.21983
}

\begin{abstract}
Abstrak
Kepemilikan dan peredaran senjata tajam di Indonesia masih sangat minim pengaturan. penelitan ini bertujuan mengetahui terkait pengaturan kepemilikan dan peredaran senjata tajam itu sendiri dan pengaturan mengenai penyalahgunaan senjata tajam. pengaturan senjata tajam diatur dalam Undang-Undang No. 12/Drt/1951 mengatur 2 hal pokok antara lain ialah Pasal 1 Undang-Undang No. 12/Drt/1951 mengatur mengenai senjata api dan secara spesifik senjata tajam diatur dalam Pasal 2 Undang-Undang No. 12/Drt/1951. Pasal 2 ayat (1) mengatur mengenai tindak-tindakan yang tidak iperbolehkan mengenai senjata tajam yang ilegsl dan juga yang disebut senjata tajam tersebut ialah senjata pemukul, senjata penikam dan senjata penusuk dan pada Pasal 2 ayat (2) mengatur mengenai klasifikasi alasan seseorang dapat memiliki senjata tajam. Dalam prakteknya pengimplementasian Pasal 2 Undang-undang No. 12/Drt/1951 masih sangat kurang karena masih banyak di Indonesia orang ditangkap dengan alasan memiliki senjata tajam yang jelas senjata tajam tersebut digunakan seusai dengan Undang-Undang dan juga terkait pengawasan mengenai senjata tajam masih sangat minim karena masih banyak di temukan senjata tajam yang jelas jelas tidak di perbolehkan beredar tetapi senjata tajam tersebut malah dijual dengan sangat bebas.

Kata Kunci: Tindak Pidana; Penyalahgunaan; Senjata Tajam.
\end{abstract}

\section{Pendahuluan}

Kepemilikan dan peredaran senjata tajam sangat bebas di Indonesia, masyarakat dapat dengan mudah dan bebas dalam memiliki senjata tajam itu sendiri, bebasnya peredaran senjata tajam tersebut dikarenakan senjata tajam tersebut tidak bisa lepas dari kehidupan masyarakat dan senjata tajam ini sendiri merupakan alat yang sering digunakan oleh masyarakat sebagai alat penunjang untuk mempermudah kehidupan masyarakat, seperti halnya pisau digunakan untuk memotong daging, arit digunakan untuk petani bercocok tanam, dan masih banyak senjata tajam lainnya yang digunakan untuk menunjang kehidupan bermasyarakat. 
Senjata tajam di Indonesia sebenarnya diatur dalam suatu peraturan perundang-undangan. senjata tajam diatur dalam Undang-Undang Nomor 12/ Drt/1951 Tentang Mengubah “Ordonantietijdelijke Bijzondere Strafbepalingen” (STBL. 1948 Nomor 17) dan Undang-Undang Republik Indonesia Dahulu Nomor 8 Tahun 1948. Undang-Undang No. 12/Drt/1951 merupakan Udang-Undang Darurat yang dijadikan Undang-Undang atas dasar Pasal 1 Undang-Undang Nomor 1 Tahun 1961 Tentang Penetapan Semua Undang-Undang Darurat dan Semua Peraturan Pemerintah Pengganti Undang-Undang yang Sudah Ada Sebelum Tanggal 1 Januari 1961 Menjadi Undang-undang. atas dasar UndangUndang No. 1 Tahun 1961.

Pengawasan yang diatur oleh Undang-Undang No. 12/Drt/1951 tidak membuat peredaran dan kepemilikan senjata tajam menjadi sulit akan tetapi semakin hari kepemilikan senjata tajam dan peredaran senjata tajam semakin marak dan bebas, contoh dari bebasnya peredaran senjata tajam ialah siapa saja dan dimana saja dapat membeli ataupun menjual senjata tajam tanpa pengawasan, dan senjata tajam dapat pula di jumpai di media online.

Dari bebasnya peredaran tersebut dewasa ini penyalahgunaan senjata tajam banyak sekali terjadi di Indonesia yang di mana senjata tajam tersebut digunakan untuk kegiatan yang melawan hukum seperti halnya mengancam, tawuran, membegal, dan kejahatan lainnya. Razia terkait penyalahgunaan senjata tajam ini kerap dilakukan oleh penegak hukum guna mengurangi intensitas disalahgunakannya senjata tajam.

Kasus mengenai kepemilikan senjata tajam menimpa seorang pemuda di Barabai yang bernama M. Rusdiyanor berusia 22 tahun yang harus berurusan dengan polisi karena ketahuan membawa senjata tajam sebilah pisau penusuk. ${ }^{1}$ Selain itu terkait penyalahgunaan senjata tajam dirasakan masyarakat Manado pada Tahun

${ }^{1}$ Hanani, 'bawa senjata mematikan, warga Mulaimin ditangkap sedang mabuk di pinggir jalan desa natih', (Banjarmasin Post, 2018) https://banjarmasin.tribunnews.com /2018/09/24/ bawa-senjata-mematikan-warga-mualimin-ditangkap-sedang-mabuk-di-pinggir-jalan-desa-natih?g, accessed 15 september 2019. 
2018, karena pada bulan januari hingga bulan Desember ada 30 warga Menado tewas dibunuh dengan cara di tusuk dan disabet dengan senjata tajam. ${ }^{2}$

Polisi Jember berhasil menangkap 15 orang begal selama Operasi Sikat Semeru berlangsung dari penangkapan tersebut polisi berhasil mengamankan barang bukti berupa senjata tajam yang digunakan para tersangka dalam menjalankan aksinya. ${ }^{3}$ Senjata tajam yang diamankan oleh polisi berupa 14 pisau, 19 celurit, dan dua bilah parang. ${ }^{4}$ Dari keterangan tersangka senjata tajam ini mereka gunakan atau meraka salahgunakan untuk dipakai sebagai alat mengacam dengan diacungkan ke korban untuk meminta barang berharga yang dimiliki oleh korban, dan para tersangka pun tidak segan melukai korban dengan senjata tajam tersebut.

Polisi Bogor berhasil menangkap peredaran jual beli senjata tajam yang dipergunakan pelajar Bogor untuk tawuran yang dimana pengungkapan jual beli senjata tajam ini bermula dari aksi tawuran yang dilakukan oleh pelajar Bogor yang telah menelan korban dan dari tawuran tersebut ditemukan berbagai macam senjata tajam, kemudian dari sana pemerintah kota Bogor bersama satuan polisi pamong praja dan satreskrim polresta Bogor kota berhasil meringkus tiga orang pelajar SMK penjual senjata tajam berjenis celurit secara online melalui operasi tangkap tangan. ${ }^{5}$ Wali kota bogor Bima Arya Sugiarto mengatakan "ini mugkin salah satu dari sekian banyak kemungkinan dari jaringan pengedar senjata tajam yang beredar di kalangan pelajar, salah satu persoalan aksi tawuran ini adalah karena adanya produksi, distribusi penjualan senjata tajam, dan permulaan diadakan penangkapan ini karena setiap adanya tawuran selalu ditemukan senjata tajam dengan berbagai bentuk dengan kemungkinan mampu menimbulkan korban jiwa, oleh karena itu peredaran senjata tajam harus diberhentikan". ${ }^{6}$

\footnotetext{
${ }^{2}<$ https://www.jawapos.com/jpg-today/31/12/2018/tahun-berdarah-di-manado-30-tewas-akibat-perkelahian-sepanjang-2018/.>, accessed 15 september 2019.

$3<$ https://jatim.tribunnews.com/2018/09/20/biasa-beroperasi-di-jember-15-orang-begal-dilumpuhkan-dan-dibuat-keok-oleh-polisi.> accessed 15 september 2019.

4 ibid.

$5<$ https://akurat.co/id-256724-read-melalui-media-sosial-pemkot-bogor-bongkar-jual-belisenjata-tajam-di-kalangan-pelajar>, accessed 15 september 2019.

6 ibid.
} 
Penyalahgunaan yang marak dan bebasnya senjata tajam tersebut membuat banyak pertanyaan sebenarnya bagaimana terkait pengawasan senjata tajam dan terkait penanganan penyaalahgunaan senjata tajam itu sendiri dan apakah bentuk dari penyalahgunaan senjata tajam merupakan perbuatan pidana ataukan bukan perbuatan pidana.

Penelitian ini menggunakan tipe penelitian yuridis normatif, yaitu penelitan hukum dengan cara melakukan penelitian secara sistematis norma-norma hukum atau peraturan perundang-undangan yang berkaitan dengan permasalahan yang diteliti, termasuk hubungan antara peraturan, penjelasannya, keberlakuannya serta perkembangan aturan hukum kedepannya.

Sesuai dengan tipe penelitian yang telah dipaparkan di atas, isu yang akan saya teliti akan membahas aturan-aturan hukum yang berkaitan dengan penyalahgunaan senjata tajam dalam lingkup normatif dan dibahas menggunakan peraturan perundang-undangan.

\section{Klasifikasi Senjata Tajam Yang Diperbolehkan Dalam UU 12/Drt/1951}

Senjata tajam di Indonesia pengaturannya diatur di dalam Undang-Undang No. 12/Drt/1951, yang di mana Undang-Undang No. 12/Drt/1951 mengatur dua pokok permasalahan yaitu terkait senjata api dan senjata tajam, senjata api diatur pada Pasal 1 dan senjata tajam diatur pada Pasal 2. jurnal ini akan memfokuskan pada Pasal 2 yang dimana mengatur terkait senjata tajam. Pasal 2 pada UndangUndang 12/Drt/1951 berbunyi antara lain:

pasal 2

(1) barang siapa tanpa hak memasukan ke Indonesia, membuat, menerima, mencoba, memperoleh, menyerahkan atau mencoba menyerahkan, menguasai, membawa, mempunyai persediaan padanya atau mempunyai dalam miliknya, menyimpan, mengangkut, menyembunyikan, mempergunakan, atau mengeluarkan dari Indonesia suatu senjata pemukul, senjata penikam, atau senjata penusuk (slag-, steek-, of stootwapen), dihukum dengan hukuman penjara setinggi-tingginya sepuluh tahun.

(2) dalam pengertian senjata pemukul, senjata penikan, senjata penusuk dalam pasal ini, tidak termasuk barang-barang yang nyata-nyata dimaksudkan untuk dipergunakan guna pertanian, atau untuk pekerjaan-pekerjaan rumah tangga 
atau untuk kepentingan melakukan dengan syah pekerjaan atau yang nyatanyata mempunyai tujuan sebagai barang pusaka atau barang kuno atau barang ajaib (merkwaardigheid).

Pasal 2 Undang-Undang No. 12/Drt/1951 menggunakan senjata pemukul, senjata penikam dan senjata penusuk sebagai terminology senjata tajam dan pada penjelasan Pasal 2 huruf e Undang-Undang Nomor 2 tahun 2002 tentang Kepolisian Negara Republik Indonesia menjelaskan yang dimaksud sebagai "senjata tajam" dalam Undang-Undang ini adalah senjata penikam, senjata penusuk dan senjata pemukul, tidak termasuk barang-barang yang nyata-nyata dipergunakan untuk pertanian, atau untuk pekerjaan rumah tangga, atau untuk kepentingan melakukan pekerjaan yang sah, atau nyata untuk tujuan barang pusaka, atau barang kuno, atau barang ajaib sebagaimana diatur dalam Undang-Undang No. 12/Drt/1951, jadi jika dilihat pada Undang-Undang No.12/Drt/1951 dan pada Undang-Undang No. 2 Tahun 2002 senjata tajam ialah sebagaimana disebut sebagai senjata pemukul senjata penikam dan senjata penusuk pada dua Undang-Undang tersebut.

Undang-Undang No. 12/Drt/1951 pada Pasal 2 ayat (1) mengatur mengenai kegiatan apa saja yang tidak diperbolehkan jika dikaitkan dengan senjata tajam yang tidak diperbolehkan di Indonesia, dan pada Pasal 2 ayat (2) mengatur mengenai atas alasan apa saja senjata tajam di perbolehkan di Indonseia. Pasal 2 ayat (1) dan Pasal 2 ayat (2) adalah dua ayat yang terkandung dalam satu pasal yang saling bersangkutan di mana Pasal 2 ayat (1) mengatur mengenai tindakan yang tidak diperbolehkan menyangkut dengan senjata tajam dan pada Pasal 2 ayat (2) mengatur terkait senjata tajam yang di perbolehkan beredar di Indonesia.

Senjata tajam yang diperbolehkan dapat dikaji melalui pengaturan pada Pasal 2 ayat (2) Undang-Undang No. 12/Drt/1951 yang di mana pasal tersebut mengatur mengenai tidak termasuk senjata pemukul, senjata penikam, atau senjata penusuk pada Pasal 2 ayat (1) bila barang-barang tersebut tidak termasuk barang-barang yang nyata-nyata digunakan guna pertanian, pekerjaan-pekerjaan rumah tangga, melakukan dengan syah pekerjaan, barang pusaka, barang kuno, barang ajaib. pada Pasal 2 ayat (2) tersebut dapat dilihat bahwa senjata tajam bisa beredar dengan legal yang apa bila memenuhi salah satu hal yang di atur pada Pasal 2 ayat (2). 
Hal-hal yang diatur pada Pasal 2 ayat (2) sudah dengan tegas mengatur peredaran senjata tajam akan tetapi hal-hal tersebut tidak memiliki penjelasan jadi sulit bagi penegak hukum untuk melakukan penindakan jika terkait senjata tajam itu sangat beredar karena alasan yang sangat luas pengertiannya karena tidak jelaskan apa yang artinya pertanian, kemudian pekerjaan-pekerjaan rumah tangga, dan hal lain yang sebagaimana diatur pada Pasal 2 ayat (2). hal yang diatur pada Pasal 2 ayat (2) Undang-Undang No. 12/Drt/1951 ada beberapa hal antara lain ialah pertanian, pekerjaan-pekerjaan rumah tangga, melakukan dengan syah suatu pekerjaan, barang kuno, barang pusaka, dan barang ajaib.

Hal pertama yang menjadi kan senjata tajam peredarannya di Indonesia ialah barang-barang guna pertanian, pertanian senidri penjelasannya ada di Pasal 1 angka 4 Undang-Undang No. 19 Tahun 2013 Tentang Perlindungan dan Pemberdayaan Petani, yang bunyinya ialah "Pertanian adalah kegiatan mengelola sumber daya alam hayati dengan bantuan teknologi, modal, tenaga kerja, dan manajemen untuk menghasilkan komoditas pertanian yang mencakup tanaman pangan, horticultural, perkebunan, dan atau peternakan dalam suatu agroekosistem. pertanian menurut Kamus Besar Bahasa Indonesia ialah sebuah kegiatan mengusahakan tanah dengan tanam-menanam atau segala kegiatan yang bertalian dengan tanam-menanam. Mosher ${ }^{7}$ seoarang ahli pertanian mengartikan pertanian sebgaai suatu bentuk produksi yang khas, yang didasarkan pada proses pertumbuhan tanaman. Secara umum pertanian ialah kegiatan manusia yang didalamnya mencakup bercocok tanam. ${ }^{8}$

Semua pengertian di atas maka dapat disimpulkan bahwa yang disebut sebagai pertanian ialah kegiatan yang berhubungan dengan tanam-menanam yang dimana menghasilkan bahan pertanian, jadi barang-barang yang biasa digunakan guna mengusahakan tanah yang berhubungan dengan tanam-menanam maka barang tersebut di perbolehkan peredarannya sebagaimana diatur pada Pasal 2 ayat (2) Undang-Undang No. 12/Drt/1951. Untuk mempertegas terkait senjata tajam

\footnotetext{
Sosial [171].

7 Johan Iskandar, 'Metodologi Memahami Petani dan Pertanian' (2006) 11 Jurnal Analisis

8 Edi Kusmadi, Pengantar Ilmu Pertanian (2016).[4].
} 
yang diperbolehkan dengan alasan pertanian ini ada Putusan Mahkamah Agung RI No. 103K/Kr/1975 menyatakan bahwa seorang petani yang di man dengan sebenar-benarnya bekerja di bidang pertanian menggunakan arit, cangkul, parang, dan senjata tajam lain yang lazimnya digunakan untuk bertani dapat digolongkan sebagai senjata tajam yang peredarannya diperbolehkan dan tidak masuk kedalam senjata tajam yang dilarang sebagaimana diatur pada Pasal 2 ayat (1) UndangUndang No. 12/Drt/1951. ${ }^{9}$

Alasan selanjutnya yang dapat membuat senjata tajam diperbolehkan ialah dengan alasan melakukan pekerjaan-pekerjaan rumah tangga. rumah sendiri menurut kamus hukum ialah bangunan gedung yang berfungsi sebgai tempat tinggal yang layak huni, sarana pembinaan keluarga, cermin harkat dan martabat penghuninya, serta asset bagi pemiliknya. ${ }^{10}$ kemudian pekerjaan rumah tangga ini sendiri ialah segala kagiatan pekerjaan yang di mana dilakukan di dalam rumah itu sendiri. dari pengertian tersebut dapat dilihat bahwa senjata tajam yang dimana alasannya digunakan untuk menunjang pekrjaan di rumah maka senjata tajam tersebut diperbolehkan dengan alasan bahwa senjata tersebut sesuai dengan Pasal 2 ayat (2) Undang-Undang No. 12/Drt/1951.

Unsur selanjutnya ialah kepentingan melakukan dengan syah pekerjaan. unsur sah ini artinya ialah berlaku, diakui oleh pihak berwenang, dilakukan menurut hukum yang berlaku. ${ }^{11}$ sah juga bisa berarti legal, menurut undang-undang, sesuai dengan undang-undang. ${ }^{12}$

Unsur sah ini dapat diartikan berarti melakukan pekerjaan yang legal, melakukan pekerjaan sesuai dengan undang-undang, atau melakukan pekerjaan menurut undang-undang. jadi senjata tajam yang diperbolehkan jika undangundang memperbolehkannya atau undang-undang mengatur suatu pekerjaan yang

9 Fransiska S., 'Tindak Pidana Berkenaan Dengan Senjata Tajam Menurut Undang- Undang Nomor 12/Darurat Tahun 1951(kajian Putusan PN Jember No. 847/Pid.B/2008/PN.Jr)', (2018) 7 Lex Crimen.[31].

${ }^{10}$ Fauzan dan Baharudin Siagian, Kamus Hukum dan Yurisprudensi (Kencana 2017). [641].

11 Fauzan dan Baharudin Siagian, Op.Cit.[643].

12 Setiawan Widagdo, Kamus Hukum (Prestasi Pustaka Publisher 2012).[511]. 
dimana dalam melaksanakan pekerjaan tersebut diharuskan memakai senjata tajam itu sendiri, jadi kepemilikan senjata tajam diperbolehkan bila suatu undang-undang memerintahkan pekerjaa tersebut untuk menggunakan senjata tajam.

Terkait melakukan pekerjaan yang sah Pasal 50 KUHP mengatur tentang orang yang melakukan perbuatan atas dasar ketentuan undang-undang tidak di pidana, jadi setiap perbuatan yang menjalankan ketentuan undang-undang adalah sah dan tidak melawan hukum asalkan perbuatan itu nyata-nyata dilakukan dengan sebenarnya dan patut. ${ }^{13}$

Melakukan pekerjaan yang sah selain menjalankan ketentuan undang-undang sebagaimana diatur Pasal 50 KUHP, yang dikatakan melakukan pekerjaan yang sah juga termasuk menjalankan perintah jabatan. menjalankan perintah jabatan diatur dalam Pasal 51 KUHP yaitu perbuatan yang dilakukan seseorang untuk melaksanakan perintah jabatan yang diberikan oleh penguasa yang memiliki wewenang tidak dipidana, ${ }^{14}$ jadi seseorang yang memiliki senjata tajam jika senjata yang ia miliki nyata-nyata dimiliki karena sebuah perintah dari seseorang yang memiliki wewenang maka dapat dikatakan kepemilikan senjata tersebut diperbolehkan sesuai dengan Pasal 2 ayat (2) Undang-Undang No. 12/Drt/1951 yaitu kepemilikannya nyata-nyata karena melakukan pekerjaan yang syah.

Melakukan pekerjaan yang sah sebagaimana telah diatur dalam Pasal 2 ayat (2) Undang-Undang No. 12/Drt/1951 ialah melakukan perbuatan atas dasar undangundang dan melakukan pekerjaan atas perintah jabatan.

Unsur selanjutnya ialah barang pusaka. Kamus Besar Bahasa Indonesia sendiri mengartikan pusaka sebagai harta benda peninggalan orang yang telah meninggal atau bisa disebut warisan dan juga bisa disebut barang yang di turunkan dari nenek moyang. ${ }^{15}$ Barang pusaka sendiri merupakan benda yang di turunkan dari nenek moyang atau benda yang telah diwariskan secara turun temurun, maka terkait senjata tajam yang merupakan senjata tajam yang telah diwariskan secara

\footnotetext{
${ }^{13}$ Andi Hamza, Asas-Asas Hukum Pidana (Rineka Cipta 2010).[170].

14 ibid.

$15<$ https://kbbi.web.id/pusaka.> accessed 25 september 2019.
} 
turun temurun kepemilikanya diperbolehkan menurut Pasal 2 ayat (2) UndangUndang No. 12/Drt/1951.

Unsur selanjutnya ialah barang kuno. Kamus besar Bahasa Indonesia mengartikan kuno sebagai lama atau berasal dari zama dahulu kala atau tidak modern. ${ }^{16}$ Barang kuno berarti adalah barang yang sudah ada sejak zama dahulu, maka terkait kepemilikan barang yang termasuk senjata tajam jika senjata tajam tersebut merupakan senjata tajam yang berasal dari zaman dahulu atau sudah berumur sangat tua maka senjata tajam tersebut diperbolehkan menurut Pasal 2 ayat (2) Undang-Undang No. 12/Drt/1951.

Unsur selanjutnya ialah barang ajaib, Kamus Besar Bahasa Indonesia mengartikan ajaib sebagai ganjil atau aneh atau jarang ada atau tidak seperti biasanya. Barang ajaib berarti barang yang ganjil atau barang yang aneh atau barang yang jarang ada, maka barang yang termasuk senjata tajam jika senjata tajam tersebut termasuk senjata tajam yang ganjil atau senjata tajam yang aneh atau senjata tajam yang jarang ada maka kepemilikannya diperbolehkan menurut Undang-undang 12/Drt/1951.

Semua unsur di atas yang mana telah dijelaskan oleh penulis ditegaskan lagi oleh undang-undang No. 12/Drt/1951 dengan kata yang nyata-nyata dimaksudkan untuk, jadi senjata tajam tersebut haruslah benar-benar peruntukannya untuk sebagaimana dimaksud dalam Pasal 2 ayat (2) Undang-undang No. 12/Drt/1951 yaitu guna pertanian, pekerjaan rumah tangga, melakukan hal yang syah, barang pusaka, barang kuno atau barang ajaib.

Terkait peredaran ataupun kepemilikan senjata tajam diatur dalam UndangUndang No. 12/Drt/1951, pada dasarnya setiap senjata tajam di Indonesia dilarang peredarannya tetapi pada Pasal 2 ayat (2) Undang-Undang No. 12/Drt/1951 diatur mengenai pengecualian terhadap larangan tersebut dengan dasar sebagai mana telah diatur dalam pasal tersebut.

Penyalahgunaan senjata tajam karena kepemilikan. penyalahgunaan menurut Kamus Besar Bahasa Indonesia yaitu sebuah proses atau cara atau 
perbuatan menyalahgunakan atau biasa disebut dengan penyelewengan, kemudian Black Law Dictionary mengartikan penyalahgunaan sebagai misuser yaitu suatu penggunaan hak secara tidak sah atau penyalahgunaan kantor atau waralaba ${ }^{17}$. Dalam konteks narkotika konsep penyalahgunaan bermula dari adanya hak dan kewajiban seseorang yang dijamin oleh hukum, terkait penyalahgunaan dalam hal narkotika adalah tindakan atau perbuatan yang dilakukan oleh orang-orang yang tidak berhak, tidak berwenang menggunakan dan mengedarkan narkotika. ${ }^{18}$ Dilihat dari konsep penyalahgunaan menurut kamus besar bahasa Indonesia, Black Law Dictionary, dan menurut narkotika itu jika dikaitkan dengan senjata tajam maka penyalahgunaan senjata tajam merupakan tindakan atau perbuatan yang dilakukan oleh orang-orang yang tidak memiliki hak atau tidak berwenang dan tidak memiliki hak menggunakan dan mengedarkan senjata tajam itu sendiri. kosnep penyalahgunaan sendiri di artikan sebagai Bab I telah menyebutkan mengenai halhal yang meliputi pembentukan pengaturan senjata tajam dan merupakan bentuk dari penyalahgunaan senjata tajam, yaitu : memiliki senjata tajam, menggunakan senjata tajam untuk melakukan perbuatan pidana, memperjual belikan senjata tajam yang tidak diperbolehkan, atau menggunakan senjata tajam untuk menakutnakuti orang atau mengancam orang.

Penggunaan senjata tajam secara khusus telah diatur pada Undang-undang No. 12/Drt/1951 yang di mana pada undang-undang tersebut mengatur senjata tajam atau pada undang-undang tersebut disebut sebagai senjata pemukul, senjata penikam, atau senjata penusuk diatur pada Pasal 2 Undang-Undang No. 12/ Drt/1951. pada pasal tersebut mengatur mengenai apa saja tindakan-tindakan yang jika dilakukan merupakan perbuatan pidana, tindakan yang dilarang pada pasal 2 ayat (1) dilarang ditakutkan dapat menimbulkan ancaman terhadap ketertiban umum. Tindakan-tindakan yang dilarang pada Pasal 2 ayat (1) ada 14 (empat belas)

\footnotetext{
${ }_{17}$ Henry Cambell Black, Black Law Dictionary $4^{\text {th }}$ edition (West Publishing co. 1968). [1153].

18 Chartika Junike Kiaking, 'penyalahgunaan narkotika menurut hukum pidana dan undang-undang Nomor 35 Tahun 2009 Tentang narkotika' (2017) 6 Lex Crimen. [106].
} 
macam yang dimana tindakan tersebut berkaitan dengan senjata tajam yang dapat dihukum dengan penjara setinggi-tingginya 10 tahun.

Tindak-tindakan tersebut antara lain ialah dilarang memasukan ke Indonesia, dilarang membuat, dilarang menerima, dilarang mencoba memperoleh, dilarang menyerahkan atau mencoba menyerahkan, dilarang menguasai, dilarang membawa, dilarang mempunyai persediaan padanya, dilarang mempunyai dalam miliknya, dilarang menyimpan, dilarang mengangkut, dilarang menyembunyikan, dilarang mempergunakan, dilarang mengeluarkan dari Indonesia, dan semuanya ialah tindakan tanpa hak jadi dapat dibilang tindakan menyalahgunakan senjata tajam.

14 (empat belas) tindakan tersebut yang di mana di atur dalam Pasal 2 ayat (1) Undang-Undang No. 12/Drt/1951 semuanya adalah perbuatan pidana dan pengklasifikasian perbuatan pidana tersebut di atur di Pasal 3 Undang-Undang No. 12/Drt/1951 yang sebagai berikut :

Perbuatan-perbuatan yang dapat dihukum menurut Undang-undang ini dipandang sebagai kejahatan.

Perbuatan pada Pasal 2 ayat (1) Undang-Undang No. 12/Drt/1951 mengenai perbuatan apa saja yang dilarang dalam Undang-Undang No. 12/Drt/1951 dan semua Perbuatan tersebut di kualifikasikan sebagai Kejahatan sebagaimana diatur pada pasal 3 Undang-Undang No. 12/Drt/1951.

Kejahatan yang dimaksud adalah merupakan perbuatan pidana dan pembagian perbuatan pidana dibagi menjadi 2 yaitu kejahatan dan pelanggaran. kejahatan adalah rectsdekicten, yaitu perbuatan-perbuatan yang pada dasarnya merupakan perbuatan pidana walaupun tidak diatur dalam undang-undang, sedangkan pelanggaran sendiri adalah wetsdelicten, yaitu perbuatan-perbuatan yang dikatakan melawan hukum karena undang-undang mengaturnya. ${ }^{19}$

Analisis di atas maka dapat di lihat bahwa Undang - Undang No.12/Drt/1951 mengatur mengenai terkait kepemilikan dan peredaran senjata tajam itu sendiri kemudian terkait penyalahgunaannya dapat dilihat pada Kitab Undang-Undang

\footnotetext{
${ }^{19}$ Moeljatno, asas-asas hukum pidana (Rineka Cipta 2015).[78].
} 
Hukum Pidana yang di mana sebagai dasar yang mengatur jenis-jenis tindak pidana di Indonesia.

\section{Pertanggungjawaban Pidana Pelaku Penyalahgunaan Senjata Tajam}

Pertanggungjawaban pidana adalah apakah seseorang dapat bertanggungjawab secara pidana jika melakukan perbuatan pidana. tidak semua perbuatan pidana dapat dipertanggungjawabkan. perbuatan pidana yang dapat dipertanggungjawabkan hanyalah perbuatan pidana yang dimana dalam melakukan perbuatan tersebut terdapat unsur kesalahan didalamnya, jadi apabila orang melakukan perbuatan pidana itu mempunyai unsur kesalahan, maka perbuatan tersebut dapat dipertanggungjawabkan secara pidana. tetapi, manakala perbuatan pidana dilakukan tanpa mempunyai unsur kesalahan didalamnya maka tidak dapat dipertanggungjawabkan secara pidana. ${ }^{20}$ tidak bertanggungjawabnya seseorang yang telah melakukan perbuatan pidana tersebut dikarenakan adanya azas dalam pertanggungjawaban dalam hukum pidana yang berbunyi Geen straf zonder schuld; actus non facit reum nisi mens sir rea yang artinya sendiri adalah tidak dipidana seseorang jika tidak ada kesalahan, azas ini merupakan azas yang hidup secara tidak tertulis di Indonesia. ${ }^{21}$

Seperti dijelaskan di atas mengenai pertanggungjawaban yang dimana terdapat azas yaitu tidak dipidana bila tidak terdapat unsur kesalahan (Geen straf zonder schuld; actus non facit reum nisi mens sir rea) dan untuk melihat apakah seseorang memiliki kesalahan orang tersebut harus:

a. Melakukan perbuatan pidana atau perbuatan yang memiliki sifat melawan hukum. seperti telah di jelaskan diatas melakukan perbuatan pidana sendiri adalah melakukan perbuatan yang dimana perbuatan itu dilarang dan diancam dengan pidana.

b. Diatas umur tertentu mampu bertanggung jawab. untuk unsur ini di bedakan menjadi 2 yaitu diatas umur tertentu dan orang tersebut harus bisa

\footnotetext{
20 ibid.

${ }^{21}$ Moeljatno, Op.Cit.[165].
} 
mempertanggungjawabkan perbuatannya. diatas umur tertentu KUHP telah mengatur pada Pasal 45 bahwa dalam hal menuntut orang yang belum cukup umur karena melakukan perbuatan sebelum umur enam belas tahun, hakim dapat menentukan yaitu dikembalikan kedapa orang tuanya, tanpa pidana apapun, diserahkan kepada pemerintah, tanpa pidana apapun atau, dipidana. untuk diatas umur tertentu ini maksudnya seseorang dapat dikatakan melakukan kesalah jika umurnya telah malampaui sebagai mana telah hukum mengatur. dalam hal mampu bertanggungjawab, orang dinyatakan mampu bertanggung jawab bila mampu menentukan niat, kehendak, rencana atas perbuatan yang dilakukannya, kemudian mengetahui atau menginsafi bahwa perbuatannya tersebut dipandang tidak patut oleh masyarakat, dan mengetahui atau menginsafi arti, makna, hakikat dari perbuatan bahwa perbuatannya baik atau buruk..$^{22}$ untuk pengaturan dalam KUHP dapat bertanggungjawab sendiri diatur pada Pasal 44 KUHP yang menentukan bahwa yang dikategorikan sebagaiorang tidak mampu bertanggungjawab sendiri ialah orang yang pertumbuhan akal sehatnya tidak sempurna atau kurang sempurna yang sebagaimana kita sering sebut sebagai idiot dan orang yang sakit jiwa.

c. Mempunyai suatu bentuk kesalahan yang berupa kesengajaan atau kelapaan, kesengajaan dan kealpaan sendiri adalah bentuk atau corak kesalahan itu sendiri, kesengajaan sendiri ada satu teori yang melandasinya yaitu teori kehendak dimana menurut teori ini seseorang dikatakan melakukan kesengajaan, memang dia berkehendak melakukan tindak pidana tersebut. ${ }^{23}$ terkait kealpaan sendiri sebenarnya hampir sama dengan kesengajaan hanya saja ada satu hal yang membedakan yaitu sikap batin orang yang melakukan perbuatan. sikap batin kesengajaan ialah menentang larangan, kemudian sikap batin kealpaan sendiri ialah kurang memperhatikan laranganyang menjadikannya tidak berhati-hati dalam melakukan perbuatan yang dampaknya menyebabkan orang tesebut

\footnotetext{
${ }_{22}$ Didik Endro Purwoleksono, Hukum Pidana (Airlangga Universitu Press 2014).[68].

23 ibid.[69].
} 
melakukan perbuatan yang dilarang. ${ }^{24}$

d. Tidak adanya alasan pemaaf, alasan pemaaf sendiri adalah alasan yang menghapus kesalahan terdakwa, di sini terdkawa melakukan perbuatan pidana, akan tetapi tidak dapat dipidananya terdakw karena terdakwa tidak memiliki kesalahan. ${ }^{25}$ tidak adanya kesalahan dari perbuatan yang dilakukan oleh orang tersebut dikarenakan perbuatan pidana yang dilakukan oleh orang tersebut dikarenakan keterpaksaan sebagaimana diatur dalam Pasal 49 KUHP yang merupakan pembelaan terpaksa dan juga diatur dalam Pasal 51 yang merupakan perintah jabatan, jadi orang tersebut melakukan perbuatan pidana bukan kehendaknya sendiri karena suatu alasan tertentu.

Senjata sendiri menurut Black Law Dictionary disebut sebagai Arma latin for Arms yang artinya adalah senjata yang digunakan untuk menyerang ataupun untuk betahan, ${ }^{26}$ senjata tajam ini merupakan pengertian senjata tajam secara luas namun dalam penulisan skripsi ini yang digunakan adalah senjata tajam dalam arti yang lebih spesifik yang di mana dalam Black Law Dictionary di jelaskan sebagai Arma Moluta yang artinya sendiri ialah senjata tajam yang dapat digunakan untuk memotong dan bukan senjata yang hanya dapat membuat memar ataupun mematahkan, ${ }^{27}$ jadi senjata tajam dalam arti yang lebih sempit ialah senjata yang tajam yang dapat digunakan untuk memotong atau untuk menyayat. Senjata tajam dalam Undang-Undang No. 2 Tahun 2002 tentang Kepolisian Republik Indonesia dijelaskan pada penjelasan Pasal 2 huruf e yaitu "yang dimaksud dengan "senjata tajam" dalam Undang-Undang ini adalah senjata penikam, senjata penusuk, senjata pemukul, tidak termasuk barang-barang yang nyata-nyata dipergunakan untuk pertanian, atau untuk pekerjaan rumah tangga, atau untuk kepentingan melakukan pekerjaan yang sah, atau nyata untuk tujuan barang pusaka, atau barang kuno, atau barang ajaib sebagai mana diatur dalam Undang-Undang No. 12/Drt/1951.” dapat

\footnotetext{
${ }^{24}$ Moeljatno, Op.Cit.[216].

25 ibid.[76].

${ }^{26}$ Henry Cambell Black, Op.Cit.[138].

27 ibid.
} 
dikatakan senjata tajam dalam Undang-Undang Kepolisian adalah senjata tajam dalam arti yang luas.

Senjata tajam dalam penelitian ini ialah senjata tajam yang di artikan dalam arti yang lebih spesifik yaitu senjata tajam yang di mana senjata tajam tersebut ialah senjata tajam yang dapat digunakan untuk memotong atau menyayat bukan sekedar senjata tajam yang digunakan untuk bertahan ataupun hanya sekedar membuat memar ataupun mematahkan.

Undang-Undang No.12/Drt/1951 mengatur dua subjek hukum yaitu orang (Natuurlijk person) dan Korporasi atau badan hukum. Seseorang dapat dikatakan sebagai pelaku atau subjek tindak pidana adalah manusia (naturlijkperson). manusia (natuurlijk person) sebagai subjek tindak pidana sebenarnya terlihat dari rumusanrumusan pidana yang ada di KUHP yang di mana pidana atau sanksi yang ada dalam KUHP yaitu berupa hukuman penjara, kurungan dan denda yang kesemua sanksi tersebut hanya dapat dilakukan oleh manusia (natuurlijk person). ${ }^{28}$

Terkait dengan pelaku perbuatan pidana yang dilakukan lebih dari satu orang diatur dalam Pasal 55 dan Pasal 56 KUHP. dalam KUHP yang berkaitan dengan masalah (deelnemers) dibedakan atas: ${ }^{29}$

1. Pelaku (dader) sebagaimana telah diatur dalam Pasal 55 KUHP;

2. Membantu melakukan (madeplictigheid) yang sebgaimana telah diatur dalam Pasal 56 KUHP.

Pasal 55 KUHP memiliki rumusan sebagai berikut:

(1) dipidana sebagai pembuat (dader) sesuatu perbuatan pidana:

ke-1. mereka yang melakukan, yang menyuruh lakukan, dan yang turut serta melakukan perbuatan.

ke-2. mereka yang dengan memberi atau menjanjikan sesuatu, dengan menyalahgunakan kekuasaan atau martabat, dengan kekerasan, ancaman atau penyesatan, atau dengan memberi kesempatan, sarana atau dengan memberi kesempatan, sarana atau keterangan, sengaja menganjurkan orang lain supaya melakukan perbuatan.

(2) terhadap penganjur hanya perbuatan yang sengaja dianjurkan sajalah

${ }_{28}$ Wirjono Prodjodikoro, Asas-Asas Hukum Pidana di IndonesiaI (Refika Aditama 2003).[59].

29 Andi Hamzah, Hukum Pidana Indonesia (Sinar Grafika 2019).[353]. 
yang diperhitungkan, beserta akibat-akibatnya.

Ketentuan Pasal 55 KUHP tersebut secara ekplisit menentukan siapa saja yang disebut sebagai pelaku, berdasarkan Pasal 55 KUHP tersebut pelaku dibedakan menjadi 4 yaitu pelaku (plager, Enkelvoudige Daderschap), orang yang membuat orang lain melakukan atau penyuruh (doen pleger), pelaku peserta (medeplegen) dan pemancing (Uitlokker).

Subjek hukum tindak pidana penyalahgunaan senjata tajam sebagai mana diatur dalam Undang-Undang No. 12/Drt/1951 selain mengatur orang juga mengatur korporasi sebagai subjek hukum yang di mana terkait korporasi di atur dalam Pasal 4 Undang-Undang No. 12/Drt/1951 sebagai berikut:

(1) Bilamana suatu perbuatan yang dapat dihukum menurut Undang-Undang ini dilakukan oleh atau atas kekuasaan suatu badan hukum maka penuntutan dapat dilakukan dan hukuman dapat dijatuhkan kepada pengurusatau wakilnya.

(2) ketentuan pada ayat (1) di muka berlaku juga terhadap badan-badan hukum, yang bertindak selaku [engurus atau wakil dari suatu badan hukum lain.

Hal menunjukan bahwa badan hukum dapat dijadikan sebagai pelaku, maka dari itu terkait dengan pertanggungjawaban pidananya pengurus atau wakil setempatlah yang menanggung tuntutan dan hukuman. ketentuan yang diatur pada Pasal 4 ayat (1) tersebut juga berlaku bagi badan-badan hukum, yang bertindak selaku pengurus atau wakil dari suatu badan hukum lain.

Sistem pembebanan pertanggungjawaban pidana korporasi memiliki 4 (empat) kemungkinan yang dapat di berlakukan yaitu, 1. pengurus korporasi sebagai pelaku tindak pidana sehingga penguruslah yang harus menanggung beban pertanggungjawaban pidana, 2. korporasi sebagai pelaku tetapi pengurus korporasi lah yang memikul beban pertanggungjawaban pidana, 3. korporasi sebagai pelaku tindak pidana dan korporasi lah yang menanggung beban pertanggungjawabannya, dan 4. pengurus dan korporasi keduanya sebagai pelaku tindak pidana dan keduanya lah yang menanggung pertanggungjawaban. ${ }^{30}$ Undang-Undang No. 12/Drt/1951 pada pasal 4 memberlakukan sistem pembebanan yang dimana korporasi lah yang

30 ibid.[115]. 
menjadi pelaku atau subjek tindak pidana tetapi penguruslah yang menanggung beban pertanggungjawaban pidananya.

Sanksi yang di jatuhkan pada pelaku penyalahgunaan senjata tajam dapat kita lihat pada Pasal 2 Undang-Undang No. 12/Drt/1951 yang di mana jika melanggar salah satu perbuatan yang diatur pada pasal tersebut dapat diancam pidana penjara selama-lamanya sepuluh tahun.

Selain menentukan pidana pokok untuk pelaku penyalahgunaan senjata tajam yaitu pidana penjara selama-lamanya sepuluh tahun Undang-Undang No. 12/ Drt/1951 juga mengatur mengenai sanksi pidana tambahan. pidana tambahan ini diatur pada pasal 5 Undang-Undang No.12/Drt/1951, yang isinya yaitu:

Pasal 5

(1) barang-barang atau bahan-bahan dengan mana atau terhadap mana sesuatu yang terancam hukuman pada pasal 1 atau 2, dapat dirampas, juga bilamana barang-barang itu tidak kepunyaan si tertuduh.

(2) barang-barang atau bahan-bahan yang dirampas menurut ketentuan ayat (1), harus dirusak, kecuali apabila terhadap barang-barang itu oleh atau dari pihak menteri pertahanan untuk kepentingan Negara diberikan suatu tujian lain.

Sanksi tambahan yang diuraikan diatas ini ialah perampasan barang-barang sebagai mana pasal 1 dan pasal 2 menentukan dan untuk selanjutnya harus dirusak atau dimusnahkan kecuali digunakan untuk kepentingan Negara.

\section{Kesimpulan}

Pengarturan yang berkaitan dengan senjata tajam hanya ada satu peraturan yaitu Undang-Undang No. 12 Drt/1951 yang di mana pengaturan terkait senjata tajam ada pada Pasal 2 ayat (1) dan Pasal 2 ayat (2). Pasal 2 ayat (1) mengatur mengenai kepemilikan dan peredaran senjata tajam dengan mencantumkan tindak-tindakan yang dikatakan tidak diperbolehkan jika dikaitkan dengan senjata tajam, dan Pasal 2 ayat (2) mengatur mengenai atas dasar apakah senjata tajam diperbolehkan di Indonesia. penyalahgunaan senjata tajam di Indonesia di atur dalam KUHP sebagai dasar perbuatan pidana di Indonesia.

Pertanggungjawaban pidana pelaku penyalahgunaan senjata tajam menurut Undang-undang No. 12/Drt/1951 memiliki 2 subjek yang dapat dikenakan 
pertanggungjawaban yaitu perseorangan yang diatur pada Pasal 2 ataupun badan hukum pada Pasal 5. pelaku penyalahgunaan senjata tajam baru dapat dikatakan harus mempertanggungjawabkan tindakanya apa bila senjata tajam yang ia bawa adalah senjata tajam diluar ketentuan pada Pasal 2 ayat (2) Undang-Undang No. 12/Drt/1951, kemudian terkait Pasal 2 ayat (2) senjata tajam tersebut sesuai masuk dalam salah satu ketentuan yang diperbolehkan karena senjata tajam tersebut benarbenar peruntukannya untuk sebagaimana diatur dalam Pasal 2 ayat (2).

\section{Daftar Bacaan}

\section{Buku}

Andi Hamza, Asas-Asas Hukum Pidana (Rineka Cipta 2010).

Andy Hamzah, Hukum Pidana Indonesia (Sinar Grafika 2019).

Baharudin Siagia dan Fauzan, Kamus Hukum dan Yurisprudensi (Kencana 2017).

Chairul Huda, Dari Tiada Pidana Tanpa Kesalahan Menuju Tiada Pertanggungjawaban Tanpa Kesalahan: Tinjauan Kritis Terhadap Teori Penisahan Tindak PIdana dan Pertanggungjawaban Pidana (Kencana 2006).

Didik Endro Purwoleksono, Hukum Pidana (Airlangga University Press 2014).

Didik Endro Purwoleksono, Hukum Pidana: Untaian Pemikiran (Airlangga University Press 2019).

Edi Kusuma, Pengantar Ilmu Pertanian (Jakarta 2016).

Henry Cambell Black, Black Law Dictionary $4^{\text {th }}$ edition (West Publishing co. 1968).

Moeljatno, Asas-Asas Hukum Pidana (Rineka Cipta 2015).

Peter Mahmud Marzuki, Penelitian Hukum (Kencana 2017).

Roeslan Saleh, Perbuatan Pidana dan Pertanggungjawaban Pidana (Aksara Baru 1983).

Setiawan Widagdo, Kamus Hukum (Prestasi Pustaka Publisher 2012).

Wirjono Prodjodikoro, Asas-Asas Hukum Pidana di Indonesia (Refika Aditama 2003). 


\section{Jurnal}

Chartika Junike Kiaking, 'penyalahgunaan narkotika menurut hukum pidana dan undang-undang Nomor 35 Tahun 2009 Tentang narkotika', (2017) VI Lex Crimen.

Johan Iskandar, 'Metodologi Memahami Petani dan Pertanian' (2006) 11 Analisis Hukum.

S., Fransiska, 'Tindak Pidana Berkenaan Dengan Senjata Tajam Menurut UndangUndang Nomor 12/Darurat Tahun 1951(kajian Putusan PN Jember No. 847/ Pid.B/2008/PN.Jr)' (2018) VII Lex Crimen.

\section{Laman}

Hanani, 'bawa senjata mematikan, warga Mulaimin ditangkap sedang mabuk di pinggir jalan desa natih' (Banjarmasin Post) <https://banjarmasin. tribunnews.com/2018/09/24/bawa-senjata-mematikan-wa rga-mualiminditangkap-sedang-mabuk-di-pinggir-jalan-desa-natih?ga=2.187 898 600.1579767225.1563060738-137770454.1558200558.> accessed 15 september 2019.

$<$ https://www.jawapos.com/jpg-today/31/12/2018/tahun-berdarah-di-manado-30tewas-akibat-perkelahian-sepanjang-2018/> accessed 15 september 2019

https://jatim.tribunnews.com/2018/09/20/biasa-beroperasi-di-jember-15-orangbegal-dilumpuhkan-dan-dibuat-keok-oleh-polisi accessed 15 september 2019.

$<$ https://akurat.co/id-256724-read-melalui-media-sosial-pemkot-bogor-bongkarjual-beli-senjata-tajam-di-kalangan-pelajar > accessed 15 September 2019.

$<$ https://jabar.tribunnews.com/2018/08/09/kejahatan-dengan-senjata-tajammenjadi-kasus-terbanyak-di-kota-sukabumi > accessed 15 September 2019.

$<$ https://kbbi.web.id/pusaka.> accessed 25 september 2019 .

$<$ https://kbbi.web.id/kuno.> accessed 25 september 2019. 
1882 Rakyu Swanabumi: Tindak Pidana dan Pertanggungjawaban

--halaman ini sengaja dibiarkan kosong-- 